\title{
PENGARUH MEKANISME CORPORATE GOVERNANCE DAN UKURAN PERUSAHAAN TERHADAP KINERJA KEUANGAN (Survei Pada Perusahaan Manufaktur yang terdaftar di BEI )
}

\author{
Animah \\ Lukman Effendy \\ Alamsyah, M.Thahir \\ Erna Widiastuty
}

\begin{abstract}
ABSTRAC
The purpose of this research is to examine the effect of corporate governance mechanisms, firm size of financial performance. The Population of this research is the company manufacturing in BEI. The sampling technique used is purposive sampling. The analytical tool used is using partial least square program. The independent variables in this research are corporate governance mechanism, firm size while the dependent variable is the performance of the financial. The result of the research shows that firm size influence to financial performance, while other variables such as corporate governance mechanisms have no effect negative to financial performance.

Keyword : Corporate Governance Mechanisms, Firm Size, Financial Performance
\end{abstract}

\section{PENDAHULUAN}

\section{Latar Belakang}

Investasi merupakan penempatan dana pada periode tertentu dengan harapan memperoleh penghasilan di masa yang datang. Hal yang perlu diperhatikan oleh calon investor sebelum melakukan investasi adalah memastikan bahwa apakah investasi tersebut mampu untuk memberikan tingkat pengembalian yang sesuai dengan harapan. Penilaian kinerja pada perusahaan yang akan menjadi sasaran investasi penting dijadikan sumber informasi untuk mengetahui kemampuannya menghasilkan tingkat pengembalian yang diharapkan investor. Investor menilai, semakin tinggi kinerja keuangan perusahaan maka, semakin baik pula return yang diperoleh oleh investor jika menanamkan modalnya pada perusahaan tersebut (Candradewi, 2015).

Penilaian kinerja keuangan perusahaan dilakukan dengan menggunakan rasio-rasio keuangan. Rasio keuangan menunjukan kemampuan perusahaan untuk memperoleh laba dan sebagai ukuran efektivitas pengelolaan manajemen perusahaan (Wiagustini, 2010:76). Selain itu rasio keuangan juga menunjukkan kemampuan untuk membayar hutang jangka pendek maupun hutang jangka panjang. 
Manajemen dan pengelolaan perusahaan semakin banyak dipisahkan dari kepemilikan perusahaan meskipun pemisahan antara pengelolaan dengan kepemilikan perusahaan akan menimbulkan konflik yang disebut dengan konflik keagenan. Manajer sebagai pengelola perusahaan cenderung memfokuskan pada proyek dan investasi perusahaan yang menghasilkan laba yang tinggi dalam jangka pendek sedangkan keinginan pemilik perusahaan adalah memaksimalkan kesejahteraan pemegang saham melalui investasi di proyek-proyek yang menguntungkan jangka panjang.

Pengelolaan perusahaan yang semakin komplek akan meningkatkan kebutuhan perusahaan untuk menerapkan praktik tata kelola perusahaan yang baik dengan tujuan untuk memastikan aktivitas manajemen dalam perusahaan akan berjalan dengan baik (Wijayanti, 2012). Good Corporate Governance (tata kelola perusahaan ) merupakan seperangkat sistem untuk mengatur hubungan antara manajer, pemilik perusahaan dan para stakeholderlainnya yang terkait dengan hak dan kewajiban mereka ( FCGI, 2002 dalam Luhgianto, 2010). Masalah utama yang mendasari penerapan Good Corporate Governance yaitu adanya pemisahan antara pengelola perusahaan dengan kepemilikan perusahaan atau disebut dengan masalah keagenan. Permasalahan keagenan timbul akibat sulitnya menyatukan kepentingan dari pihak pemilik dengan pengelola. Untuk itu dibutuhkan Good Corporate Governance untuk mengurangi permasalahan keagenan antara pemilik dan manajer (Macey dan O'Hara, 2003).

Penelitian yang dilakukan Darwis (2007) menunjukkan bahwa Good Corporate Gorvernance berpengaruh positif dan signifikan terhadap kinerja keuangan perusahaan. Good Corporate Gorvernance bermanfaat dalam menekan biaya keagenan dan membuat efisiensi operasional perusahaan sehingga meningkatkan kinerja keuangan perusahaan. Penelitian lain yang dilakukan Sekaredi (2011) yang meneliti mekanisme Good Corporate Governance terhadap kinerja keuangan perusahaan menemukan bahwa mekanisme Good Corporate Governance tidak berpengaruh terhadap kinerja keuangan perusahaan karena penerapan Good Corporate Governance dilihat dari jangka waktunya bersifat jangka panjang

Faktor lain yang mendasari kontribusi peningkatan kinerja keuangan perusahaan adalah struktur kepemilikan. Struktur kepemilikan merupakan proporsi pemegang saham di dalam perusahaan yang dihitung dengan jumlah saham yang dimiliki pemilik dibagi dengan seluruh saham perusahaan. Proporsi dalam kepemilikan ini akan menentukan jumlah minoritas dan mayoritas kepemilikan saham dalam perusahaan (Abdurrahman, 2005). Kepemilikan manajerial dan kepemilikan institusional adalah dua mekanisme yang dapat mengurangi masalah keagenan (Jensen \& Mackling, 1976). Kepemilikan manajerial merupakan kepemilikan saham oleh manajemen perusahaan yang diukur dengan persentase jumlah saham yang dimiliki oleh pengelola perusahaan (Sujono dan Soebiantoro, 2007). 
Semakin besar proporsi kepemilikan manajemen pada perusahaan akan dapat menyatukan kepentingan antara manajer dengan pemegang saham, sehingga kinerja perusahaan semakin bagus (Jensen \& Mackling, 1976). Sedangkan Kepemilikan institusional merupakan persentase saham institusi baik swasta maupun pemerintah di dalam maupun di luar negeri (Sam'ani, 2008). Tingkat kepemilikan institusional yang tinggi akan menimbulkan usaha pengawasan yang lebih besar oleh pihak investor institusional sehingga dapat menghalangi perilaku opportunistic manajer (Wiranata, 2013).

Hasil penelitian Nur'aeni (2010) menunjukkan bahwa kepemilikan institusional berpengaruh positif terhadap kinerja keuangan perusahaan. Hal ini karena semakin tinggi kepemilikan institusional maka semakin tinggi pula dorongan pihak institusi dalam mengawasi manajemen sehingga memberikan dorongan lebih besar dalam peningkatan kinerja keuangan perusahaan. Penelitian lainnya dari Hapsoro (2008) menyatakan bahwa kepemilikan institusional tidak berpengaruh terhadap kinerja keuangan perusahaan disebabkan disebabkan ikut sertanya pemilik mayoritas institusi mengendalikan perusahaan sehingga menimbulkan celah untuk bertindak sesuai kepentingannya walaupun harus mengorbankan kepentingan pemilik minoritas.

Penelitian terdahulu mengenai kepemilikan manajerial dilakukan oleh Gill dan Obradovich (2012) menyatakan kepemilikan manajerial mempunyai pengaruh positif terhadap kinerja keuangan perusahaan. Besarnya kepemilikan saham manajerial mengindikasikan kesamaan kepentingan antara manajemen dengan shareholders sehingga membuat kinerja keuangan perusahaan semakin baik. Berbeda dengan Wiranata (2013) yang menyatakan bahwa kepemilikan manajerial tidak berpengaruh terhadap kinerja keuangan perusahaan. Hal ini disebabkan karena proporsi kepemilikan manajerial terlalu rendah proporsinya sehingga kinerja manajer untuk mengelola perusahaan tidak optimal dan manajer sebagai pemilik saham minoritas kurang berpartisipasi aktif dalam membuat keputusan di perusahaan.

Hal lain yang mendasari perubahan kinerja keuangan perusahaan adalah size perusahaan. Menurut Ambarwati (2015), perusahaan dengan total asset yang besar mencerminkan kemapanan perusahaan. Perusahaan yang sudah mapan biasanya kondisi keuangannya juga sudah stabil. Hasil penelitian Nugraheni dan Hapsoro (2007) juga penelitian Arini (2009) mengungkapkan bahwa ukuran perusahaan berpengaruh positif terhadap ROA. Namun berbeda dengan hasil penelitian Kosmidou (2008) juga penelitian Dietrich dan Wanzenried (2011) yang mengungkapkan bahwa ukuran perusahaan berpengaruh negatif terhadap ROA. Berdasarkan latar belakang masalah, maka rumusan masalah dalam penelitian ini adalah "Apakah terdapat pengaruh mekanisme corporate governance dan ukuran perusahaan terhadap kinerja keuangan". 


\section{TINJAUAN PUSTAKA}

\section{Teori Keagenan (Agency theory)}

Eisenhardt (1989) dalam Mardiyah (2002) menyatakan bahwa teori keagenan menggunakan tiga asumsi sifat manusia, yaitu: 1 ) manusia pada umumnya mementingkan diri sendiri (self-interest), 2) manusia memiliki daya pikir terbatas mengenai persepsi masa datang (bounded-rationality), dan 3) manusia selalu menghindari risiko (risk-averse).

Berdasarkan asumsi yang melandasi teori keagenan, pemisahan antara kepemilikan dan pengelolaan perusahaan dapat menimbulkan masalah keagenan (agency problem). Dalam hubungan keagenan, pemilik perusahaan akan memberikan kewenangan pada pengelola (manajer) untuk mengurus jalannya perusahaan seperti mengelola dana dan mengambil keputusan perusahaan lainnya untuk dan atas nama pemilik perusahaan, maka mungkin saja pengelola tidak bertindak yang terbaik untuk kepentingan pemilik karena adanya perbedaaan kepentingan (conflict of interest). Pada kenyataannya, perubahan kemakmuran manajer sangat kecil dibandingkan dengan perubahan kemakmuran pemegang saham, sehingga manajer cenderung untuk mencari keuntungan sendiri (moral hazard) dengan mengorbankan kepentingan pihak lain. Hal ini dapat terjadi karena manajer mempunyai infornasi mengenai perusahaan, yang tidak dimiIiki pemilik perusahaan (asymmetric information) Jansen dan Mackling, (1976).

Adanya kecenderungan agent untuk mencari keuntungan sendiri, ini mengharuskan perusahaan mengeluarkan kos pengawasan yang disebut agency cost, Jensen dan Mackling (1976) membagi biaya keagenan ini menjadi monitoring cost, bonding cost dan residual loss. Monitoring cost adalah biaya yang timbul dan ditanggung oleh principal untuk memonitor perilaku agent, yaitu untuk mengukur, mengamati, dan mengontrol perilaku agen. Bonding cost merupakan biaya yang ditangung oleh agent untuk menetapkan dan mematuhi mekanisme yang menjamin bahwa agent akan bertindak untuk kepentingan principal. Selanjutnya residual loss merupakan pengorbanan yang berupa berkurangnya kemakmuran principal sebagai akibat dari perbedaan keputusan agent dan keputusan principal.

\section{Pengaruh Kepemilikan Institusional Terhadap Kinerja Keuangan}

Eriandani (2013), mengemukakan kepemilikan institusional merupakan salah satu faktor yang dapat mempengaruhi kinerja perusahaan. Dengan tingginya investor institusional akan mendorong peningkatan pengawasan yang lebih optimal terhadap kinerja manajemen karena pada umumnya pihak institusi memiliki divisi investasi tersendiri sehingga menimbulkan usaha pengawasan yang lebih besar dan ketat yang kemudian dapat menghalangi perilaku opportunistic manajer sehingga 
kepentingan antara pengelola dan pemilik dapat selaras hal ini dapat berdampak positif terhadap kinerja perusahaan.

Pizarro et al. (2006) dan Bjuggren et al. (2007) menemukan bahwa kepemilikan institusional berpengaruh secara positif terhadap kinerja perusahaan. Suranta dan Merdistusi (2005) melakukan penelitian di Indonesia, menyimpulkan bahwa investor institusional mampu berperan pada peningkatan kinerja perusahaan.

H1: Kepemilikan institusional berpengaruh positif terhadap kinerja keuangan

\section{Pengaruh Kepemilikan Manajerial Terhadap Kinerja Keuangan}

Menurut Jensen dan Mackling (1976) kinerja perusahaan dipengaruhi oleh distribusi kepemilikan saham insider ownership, dalam kerangka ini kepemilikan saham oleh manajemen akan mengurangi konflik keagenan. Kerena dengan adanya kepemilikan saham manajemen, maka manajemen akan ikut memperoleh manfaat langsung atas keputusan- keputusan yang diambilnya, namun juga akan menanggung risiko secara langsung bila keputusan itu salah. Ross, et al (1999) dalam Tarjo (2007) menyatakan bahwa semakin besar proporsi kepemilikan manajemen pada perusahaan, maka manajemen cenderung berusaha giat untuk kepentingan pemegang saham yang tidak lain dirinya sendiri. Sehingga dapat dikatakan kepemilikan saham oleh manajemen akan membuat manajemen termotivasi dalam meningkatkan kinerja perusahaan.

Hermalin dan Weisbach (1991) meneliti pengaruh kepemilikan manajerial, hasil penelitian menunjukkan bahwa kepemilikan manajerial berpengaruh positif terhadap kinerja keuangan perusahaan. Hal ini sejalan dengan penelitian yang dilakukan Oswald dan Jahera (1991) yang menyatakan bahwa kepemilikan manajerial dapat meningkatkan kinerja perusahaan.

H2: Kepemilikan manajerial berpengaruh positif terhadap kinerja keuangan

\section{PengaruhDewan Komisaris Independen Terhadap Kinerja Keuangan}

Komisaris independen adalah anggota dewan komisaris yang tidak memiliki hubungan keuangan, kepengurusan, kepemilikan saham, dan/hubungan keluarga dengan anggota dewan komisaris lainnya, direksi dan/pemegang saham pengendali atau hubungan lain yang dapat mempengaruhi kemampuannya untuk bertindak independen (PBI No 8/4/PBI/2006). Peran dewan komisaris dalam suatu perusahaan lebih ditekankan pada fungsi monitoring dari kebijakan direksi berdasarkan perspektif agensi, fungsi monitoring sangat krusial dalam melimitasi tindakan oportunis agen dan mereduksi biaya keagenan Wardhani (2008).

Hubungan antara komisaris independen dan kinerja perbankan juga didukung oleh perspektif bahwa dengan adanya komisaris independen 
diharapkan dapat memberikan fungsi pengawasan terhadap perusahaan secara objective dan independen, menjamin pengelolaan yang bersih dan sehatnya operasi perusahaan sehingga dapat mendukung kinerja perusahaan (Jones, 1997 dalam Purno dan Khafid, 2013). Penelitian yang dilakukan Rosyada (2012) juga menunjukkan bahwa komisaris independen berpengaruh positif terhadap kinerja keuangan.

H3: Dewan komisaris independen berpengaruh positif terhadap kinerja keuangan

\section{Pengaruh Ukuran Dewan Direksi Terhadap Kinerja Keuangan}

Para direktur memiliki dua fungsi utama sebagai pembuat keputusan manajemen (strategi perusahaan dalam jangka pendek, kebijakan investasi dan keuangan) dan mengendalikan keputusan (kompensasi manajerial, pengawasan dan alokasi modal) Fama dan Jansen, (1983). Dewan direksi dapat memberikan kontribusi terhadap kinerja perusahaan melalui aktivitas evaluasi dan keputusan strategic serta pengurangan inefisiensi dan kinerja yang rendah (Faisal, 2005). Dengan semakin banyaknya jumlah dewan direksi akan membuat koordinasi dan operasional antar bagian dalam sebuah perusahaan perbankan akan menjadi semakin efektif yang kemudian dapat meningkatkan kinerja perusahaan sendiri. Faisal (2005) menyatakan bahwa ukuran dewan direksi berhubungan positif dengan kinerja perusahaan.

H4: Ukuran dewan direksi berpengaruh positif terhadap kinerja keuangan

\section{Pengaruh Ukuran Perusahaan Terhadap Kinerja Keuangan}

Ukuran perusahaan merupakan salah satu variabel penting dalam pengelolaan perusahaan. Ukuran perusahaan mencerminkan seberapa besar penjualan yang diperoleh perusahaan. Penjualan (sales) merupakan kegiatan utama suatu perusahaan yang memiliki pengaruh strategis terhadap perusahaan dan berkaitan dengan kompetisi dalam industri. Agar dapat melakukan penjualan perusahaan membutuhkan aktiva perusahaan. Peningkatan penjualan harus diikuti dengan peningkatan aktiva perusahaan (Weston dan Brigham, 1998). Angka penjualan yang tinggi mempengaruhi keuntungan yang diperoleh perusahaan.

Perusahaan besar cenderung mendapat perhatian lebih dari masyarakat luas. Dengan demikian, biasanya perusahaan besar memiliki kecenderungan untuk selalu menjaga stabilitas dan kondisi perusahaan. Untuk menjaga stabilitas dankondisi ini, perusahaan tentu saja akan berusaha mempertahankan dan terus meningkatkan kinerjanya.

Ukuran perusahaan bisa dilihat dari total asset perusahaan. Menurut Ambarwati et. al. 2015 perusahaan dengan total asset yang besar mencerminkan kemapanan perusahaan. Perusahaan yang sudah mapan biasanya kondisi keuangannya juga sudah stabil. Selain itu, ukuran bank 
yang besar lebih diinginkan karena memungkinkan bank menyediakan menu jasa keuangan yang lebih luas (Bashir, 1999 dalam Basir 2003).

Hal senada juga diungkapkan Sudarmadji dan Sularto (2007), dimana perusahaan besar yang mempunyai sumber daya yang besar pula akan melakukan pengungkapan lebih luas dan mampu membiayai penyediaan informasi untuk keperluan internal. Informasi tersebut sekaligus menjadi bahan untuk keperluan pengungkapan informasi kepada pihak eksternal seperti investor dan kreditor, sehingga tidak memerlukan tambahan biaya yang besar untuk melakukan pengungkapan lebih luas. Dengan demikian, perusahaan yang besar mempunyai biaya produksi informasi yang lebih rendah daripada perusahaan kecil.

Suatu perusahaan besar dan mapan akan mudah untuk menuju ke pasar modal. Karena kemudahan untuk berhubungan dengan pasar modal, maka berarti fleksibilitas lebih besar dan tingkat kepercayaan investor juga lebih besar karena mempunyai kinerja operasional yang lebih besar, Perusahaan besar mampu menarik minat investor yang lebih besar dibandingkan dengan perusahaan kecil, karena mempunyai fleksibilitas penempatan investasi yang lebih baik.

H1 : Ukuran perusahaan berpengaruh positif terhadap kinerja keuangan

Berdasarkan perumusan hipotesis di atas, maka model penelitian ini dapat digambarkan sebagai berikut :

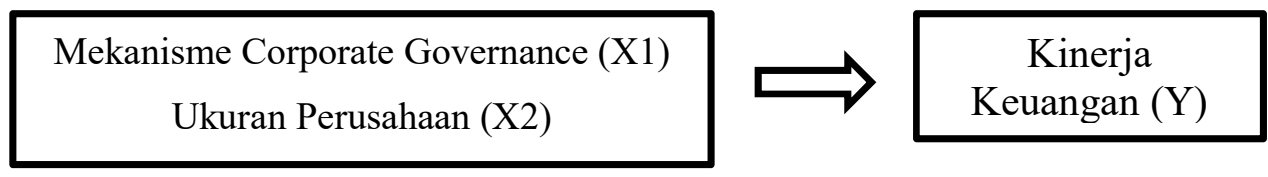

Gambar 1 : Model Penelitian

\section{METODE PENELITIAN}

Jenis penelitian ini adalah kuantitatif dengan menggunakan data sekunder yang berupa laporan keuangan perusahaaan manufaktur yang tercatat di BEI selama periode 2013 sampai 2015 melalui www.idx.co.id, sehingga metode pengambila data dinamakan dengan metode dokumentasi dan studi pustaka. Adapun populasi dalam penelitian ini adalah seluruh perusahaan manufaktur yang listing periode 2013 - 2015. Dengan teknik penentuan sampel yang digunakan adalah purposive sampling. Hasil dari teknik sampling diperoleh sampel 15 perusahaan, karena tahun penelitian 3 tahun, maka total sampling menjadi 45.

Variabel-variabel dalam penelitian ini adalah variable Variabel dependen yaitu kinerja dan variabel independen yaitu mekanisme corporate governance dan ukuran perusahaan. Adapun definisi operasional variable dalam penelitian ini adalah sebagai berikut :

a. Mekanisme Corporate Governance 
Dalam penelitian ini proksi untuk mengukur mekanisme corporate governance menggunakan :

1) Komite Audit

Keberadaan komite audit di perusahaan sudah menjadi kewajiban, seperti dalam pasal 70 Undang-Undang No. 17 Tahun 2003 Tentang Ketenagakerjaan, disebutkan bahwa komisaris dan dewan pengawas BUMN wajib membentuk komite audit yang bekerja secara kolektif dan berfungsi membentuk komisaris dan dewan pengawas dalam menjalankan tugasnya. Dalam penelitian ini komite audit diukur dengan jumlah anggota komite audit pada sebuah perusahaan.

2) Dewan Direksi

Dewan direksi merupakan proporsi jumlah anggota dewan direksi yang menjabat sebagai komisaris atau direksi di perusahaan lain terhadap total jumlah anggota dewan (komisaris dan direksi). Dalam penelitian ini dewan direksi diukur dengan jumlah anggota dewan direksi pada sebuah perusahaan.

3) Kepemilikan Institusional

Susiana dan Herawaty (2007) dalam Fajaryani (2015) menyatakan Kepemilikan Institusional merupakan persentase saham perusahaan yang dimiliki oleh perusahaan lain baik yang berada di dalam maupun luar negeri serta saham pemerintah dalam maupun luar negeri.

$$
\mathrm{KI}=\frac{\text { Jumlah saham yang dimiliki institusional }}{\text { Jumlah saham yang beredar }}
$$

4) Kepemilikan Manajerial

Kepemilikan Manajerial merupakan proporsi saham yang dimiliki manajemen yang secara aktif turut dalam pengambilan keputusan perusahaan, meliputi direksi dan komisaris (Fajaryani, 2015). $\mathrm{KM}=\frac{\text { Jumlah saham yang dimiliki institusioJumlah saham yang dimiliki manajemen nal }}{\text { Jumlah saham yang beredar }}$

b. Ukuran Perusahaan

Ukuran Perusahaan merupakan besar kecilnya suatu perusahaan yang dapat dilihat dari total aset (Murdoko dan Lana, 2007 dalam Fajaryani, 2015). Ukuran perusahaan adalah suatu skala yang dapat diklasifikasikan besar kecil perusahaan menurut berbagai cara, antara lain: total aktiva, log size, nilai pasar saham, dan lain-lain (Suwito dan Herawaty, 2005).

c. Kinerja Keuangan (Sawir, 2009)

- Profitabilitas

Profitabilitas dalam Kaitannya dengan Asset

Ukuran untuk menilai seberapa besar tingkat pengembalian dari aset yang dimiliki perusahaan

$$
R O A=\frac{\text { LabaNetoSebelumPajak }}{\text { TotalAset }}
$$

Imbal Hasil atas Ekuitas (Return on Equity - ROE) 
Pengukuran ringkasan lainnya atas kinerja keseluruhan perusahaan adalah imbal hasil atas ekuitas. ROE membandingkan laba neto setelah pajak (dikurangi dividen saham biasa) dengan ekuitas yang telah diinvestasikan pemegang saham di perusahaan. Rasio ini menunjukkan daya untuk menghasilkan laba atas investasi berdasarkan nilai buku para pemegang saham, dan sering kali digunakan dalam membandingkan dua atau lebih perusahan dalam sebuah industri yang sama.

ROE $=\frac{\text { LabaNetoSetelahPajak }}{\text { EkuitasPemegangSaham }}$

Margin Laba Neto. Margin laba neto adalah ukuran profitabilitas perusahaan dari penjualan setelah memperhitungkan semua biaya dan pajak penghasilan.

Margin Laba Neto $=\frac{\text { LabaNetoSetelahPajak }}{\text { PenjualanNeto }}$

- Likuiditas

Rasio likuiditas adalah rasio yang digunakan untuk mengukur kemampuan perusahaan untuk memenuhi liabilitas jangka pendeknya. Rasio ini membandingkan liabilitas jangka pendek dengan sumber daya jangka pendek (atau lancar) yang tersedia untuk memenuhi liabilitas tersebut. Rasio likuiditas yang umum dipergunakan untuk mengukur tingkat likuiditas suatu perusahaan antara lain:

Rasio Lancar / Current Ratio

Rasio lancar atau current ratio merupakan rasio untuk mengukur kemampuan perusahaan dalam membayar liabilitas jangka pendeknya dengan menggunakan aset lancarnya.

Current Ratio $=\frac{\text { AsetLancar }}{\text { LiabilitasJangkaPendek }}$

Rasio Cepat / Quick Ratio

Rasio ini menunjukkan kemampuan perusahaan untuk memenuhi liabilitas jangka pendek dengan aset yang paling likuid (cepat). Rasio ini berfungsi sebagai pelengkap rasio lancar dalam menganalisis likuiditas. Rasio ini sama dengan rasio lancar, hanya saja rasio tersebut tidak meliputi persediaan. Rasio ini berkonsentrasi hanya pada aset lancar yang lebih likuid (kas, sekuritas yang dapat diperjualbelikan, dan piutang) dan hubungannya dengan berbagai obligasi jangka pendek. Jadi, rasio ini memberikan ukuran yang mendalam tentang likuiditas daripada rasio lancar.

Quick Ratio $=\frac{\text { AsetLancar }- \text { Persediaan }}{\text { LiabilitasJangkaPendek }}$

- Solvabilitas

Rasio utang adalah rasio yang menunjukkan sejauh mana perusahaan dibiayai oleh utang.

Rasio Utang terhadap Ekuitas / Debt to Equity Ratio (DER) 
Untuk dapat menguji sejauh mana perusahaan menggunakan utang yang dipinjam, kita dapat menggunakan beberapa rasio utang (debt ratio) yang berbeda. Rasio utang terhadap ekuitas dihitung hanya dengan membagi total utang perusahaan (termasuk liabilitas jangka pendek) dengan ekuitas pemegang saham.

$D E R=\frac{\text { TotalUtang }}{\text { EkuitasPemegangsaham }}$

Rasio Utang terhadap Total Aset / Debt to Total Assets Ratio (DAR) Rasio ini berfungsi dengan tujuan yang hamper sama dengan rasio utang terhadap ekuitas. Rasio ini menekankan pada peran penting pendanaan utang bagi perusahaan dengan menunjukkan persentase aset perusahaan yang didukung oleh pendanaan utang. Jadi, $45 \%$ dari aset perusahaan didanai oleh utang (dari berbagai jenis), sementara sisanya $55 \%$ pendanaan berasal dari ekuitas pemegang saham.

$$
D A R=\frac{\text { TotalUtang }}{\text { TotalAset }}
$$

\section{Prosedur Analisis Data}

Prosedur analisis data yang digunakan oleh penelitian di dalam penelitian meliputi :

a. Statistik deskriptif yaitu untuk memberikan gambaran tentang tanggapan responden mengenai variabel-variabel penelitian, yang menunjukan angka kisaran teoritis dan sesungguhnya, rata-rata, serta standar deviasi.

b. Uji kualitas data (uji reliabilitas dan uji Validitas)

Uji validitas digunakan untuk menilai sah atau tidaknya suatu kuesioner.Suatu kuesioner dikatakan valid jika pertanyaan kuesioner tersebut mampumengungkapkan suatu yang diukur oleh kuesioner tersebut. Uji validitasdilakukan dengan menggunakan evaluasi measurement (outer model )yaitudengan menggunakan convergentvalidity. Convergentvalidity dari measurement model dengan indikator refleksif dapat dilihat dari korelasi antar masing-masing skor indicator dengan skor konstruknya, (Ghozali, 2014). Ukuran refleksif dikatakan tinggi jika berkolerasi lebih dari 0,70 dengan konstruk yang ingin diukur.

Uji reliabilitas dilakukan dengan melihat nilai composite reliability yangdilakukan dari hasil perhitungan PLS untuk masing-masing variable maupun konstruk. Suatu variable maupun konstruk dikatakan reliable jika memberikan nilai composite reliability $>0,70$ (Werts et al. 1974 dalam Ghazali, 2014).

c. Metode analisa data

Pengukuran antar variabel dalam penelitian ini menggunakan analisis StructuralEquation Modeling (SEM) dengan metode alternatif Partial Least Square (PLS). 


\section{HASIL ANALISIS DAN PEMBAHASAN}

\section{Gambaran Umum Objek Penelitian}

Objek dalam penelitian ini adalah perusahaan yang terdaftar di BEI dan termasuk dalam sektor manufaktur dari tahun 2013-2015 berjumlah 147 perusahaan. Berdasarkan metode purposive sampling, terdapat 15 perusahaan yang menjadi sampel penelitian ini (Citra Turbindo, Duta Pertiwi Nusantara, Gudang Garam, Indofood, Kedawung Setia Industrial, Lion Metal Works, Lionmesh Prima, Pyramid Farma, Beton Jaya Manunggal, Chandra Asri Petrochemical, Indo Acida Pratama, Tempo Scan Pacific, Wismilak Inti Makmur, Asahi Mas Flat Glass, Astra International). Periode yang digunakan dalam penelitian ini adalah 3 tahun, yakni 2013, 2014, dan 2015, sehingga total observasi berjumlah 45 perusahaan.

Variable penelitian mekanisme corporate governance menggunakan kepemilikan institusional, kepemilikan manajerial, komisaris independen, dewan direksi, komite audit sedangkan ukuran perusahaan menggunakan In total assets, In total penjualan, In laba dan kinerja keuangan ratio profitabilitas (ROA,ROE,NPM), likuiditas (DAR dan DER) dan solvabilitas (CR dan $\mathrm{QR})$.

\section{Analisis Deskriptif}

Analisis statistik deskriptif digunakan untuk melihat gambaran atau deskripsi data yang digunakan sebagai sampel. Statistik deskriptif menggambarkan distribusi data yang terdiri dari nilai minimum, nilai maksimum, nilai rata-rata dan nilai standar deviasi atas data yang digunakan dalam penelitian (Gozali, 2011). Berikut hasil analisis statistik deskriptif pada variabel eksogen yaitu mekanisme corporate governance dan ukuran perusahaan dan pada variabel endogen yaitu kinerja keuangan yang diproksikan dengan $C R, Q R, D E R, D A R, N P M, R O I, R O A, R O E$. Berikut adalah deskripsi dari masing-masing variabel penelitian dapat dilihat pada table di bawah ini :

Tabel 1

Deskriptif Data

\begin{tabular}{|l|r|r|r|l|}
\hline Variabel & \multicolumn{1}{|l|}{ Min } & Max & Mean & Stdev \\
\hline Ln Ekuitas & 25,26551 & 32,47152 & 28,0489 & 2,180098 \\
\hline Ln T. Penjualan & 24,93805 & 32,93781 & 28,53184 & 2,287729 \\
\hline LnLaba & 0 & 30,73547 & 25,17245 & 4,474681 \\
\hline Ln Asset & 14,43737 & 33,13405 & 26,47432 & 4,809234 \\
\hline Kep. Man. & 0,00004 & 0,2561 & 0,063774 & 0,081286 \\
\hline Kep. Ins. & 0,2248 & 0,9533 & 0,651215 & 0,198844 \\
\hline Size Direksi & 3 & 11 & 6,104167 & 2,707276 \\
\hline Kom. Ind. & 0,285714 & 0,75 & 0,385092 & 0,099961 \\
\hline
\end{tabular}




\begin{tabular}{|l|r|r|r|r|}
\hline Variabel & \multicolumn{1}{|l|}{ Min } & Max & Mean & Stdev \\
\hline Size Komisaris & 2 & 11 & 4,895833 & 2,442876 \\
\hline Komite Aud. & 3 & 4 & 3,145833 & 0,356674 \\
\hline CR & 1,102927 & 13,35009 & 3,324709 & 2,822189 \\
\hline QR & 0,159494 & 10,70819 & 2,134773 & 2,36213 \\
\hline DER & 0,057259 & 2,106433 & 0,634883 & 0,449032 \\
\hline DAR & 0,042615 & 0,678087 & 0,345764 & 0,162739 \\
\hline NPM & 0,004401 & 0,50873 & 0,08883 & 0,080333 \\
\hline ROI & 0,005783 & 0,260584 & 0,079487 & 0,05904 \\
\hline ROA & 0,008954 & 0,340577 & 0,104458 & 0,075576 \\
\hline ROE & 0,01292 & 0,376186 & 0,123947 & 0,087156 \\
\hline
\end{tabular}

Sumber : Data diolah

Pada variabel kepemilikan manajerial dan quik ratio yang memiliki standar deviasi lebih besar daripada rata-ratanya, sedangkan variabel In ekuitas, In penjualan, In laba, In assets, kepemilikan institusional, size direksi, komisaris independen, size komisaris, komite audit, CR, DER, DAR, NPM, ROI, ROA, dan ROE memiliki standar deviasi lebih rendah dari rataratanya.

\section{Statistik Inferensial}

Statistik inferensial, (sering juga disebut statistik induktif atau statistik probabilitas), analisis data pada penelitian ini menggunakan Structural Equation Modelling (SEM) berbasis varian atau biasa disebut dengan soft modeling, denganmenggunakan alat analisis Partial Least Square (PLS). Alat bantu atau softwareyang digunakan untuk memprediksi pengaruh variabel laten dalam penelitian iniberupa Smart PLS Versi 3.2.1.

\section{Pengujian Model Pengukuran (Outer Mode/)}

Model pengukuran digunakan untuk menguji validitas konstruk dan reliabilitas instrumen. Uji validitas dalam penelitian ini yaitu convergent validity dan discriminant validity, sedangkan untuk uji reliabilitas yaitu compositereliability. Proses pengujian model pengukuran (Outer Model) melalui pengujian validitas dan reliabilitas indikator terhadap konstruk dilakukan melalui langkah-langkah sebagai berikut :

\section{PengujianConvergent Validity}

Convergent validity dari model pengukuran dengan refleksif indicator dinilai berdasarkan korelasi antara item score/component score dengan construct score yang dihitung dengan PLS (Ghozali, 2014:24). Hal senada juga disampaikan oleh Hartono (2011:71) uji validitas konvergen dalam PLS dengan indikator reflektif dinilai berdasarkan loading factor (korelasi antara skor item/skor komponen dengan skor konstruk) indikator-indikator yang mengukur konstruk tersebut. Menurut Chin (1995) dalam Hartono, 
(2011:71) rule of thumb yang digunakan untuk validitas konvergen adalah outer loading $>0,7$. Communality $>0,5$ dan Average Variance Extracted $(A V E)>0,5$. Hasil analisis dapat dilihat pada gambar berikut ini:

\section{Gambar 2. Hasil Analisis}

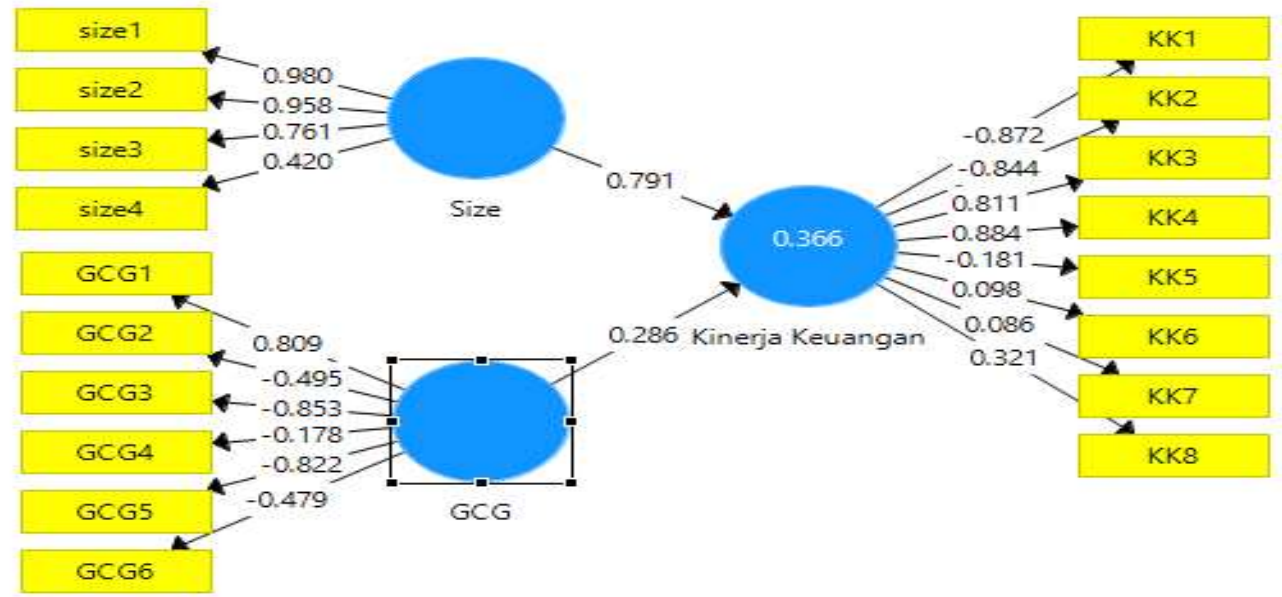

Berdasarkan hasil analisis, masih terdapat variabel manifes/teramati/indikator yang memiliki nilai loading factor $<0,50$, yaitu Size4, GCG2, GCG3, GCG4, GCG5, GCG6, KK1, KK2, KK5, KK6, KK7, dan KK8, maka indikator-indikator tersebut harus di drop dari model.

Setelah indikator-indikator tersebut didrop, selanjutnya dilakukan analisis kembali terhadap model. Berdasarkan hasil analisis, indikatorindikator memiliki nilai loading factor $>0,50$. Hasil analisis dapat dilihat pada Gambar berikut:

\section{Gambar 3. Model Pengukuran (OuterMode)}

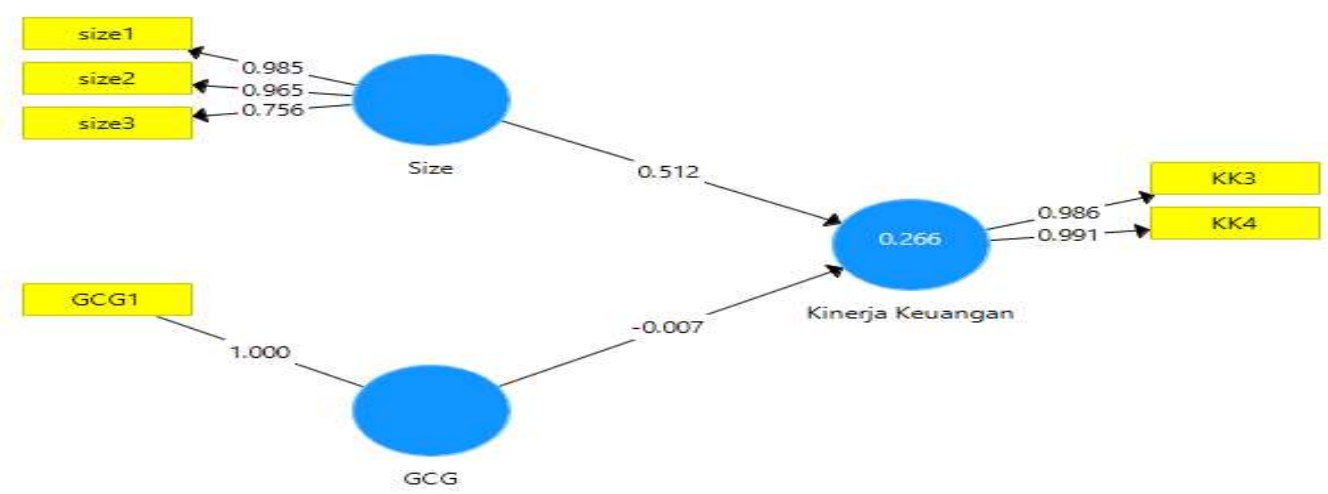

Model struktural awal telah mengalami perubahan menjadi seperti Gambar di atas, perubahan ini terjadi karena variabel manifest /teramati /indikator yang memiliki nilai loading factor $<0,50$ di drop dari model. 


\section{Pengujian Discriminant Validity}

Discriminant validity dari model pengukuran dengan refleksif indikator dinilai berdasarkan cross loading pengukuran dengan konstruknya. Metode lain untuk menilai discriminant validity adalah membandingkan nilai square root of average variance extrated (AVE) setiap konstruk dengan korelasi antara konstruk dengan konstruk lainnya dalam model. Dalam penelitian ini metode yang dipakai adalah dengan melihat nilai cross loading. Nilai cross loading dapat dilihattable berikut:

Tabel 2. Nilai Cross Loading

\begin{tabular}{|l|c|c|c|}
\hline & GCG & $\begin{array}{l}\text { Kinerja } \\
\text { Keuangan }\end{array}$ & \multicolumn{1}{l|}{ Size } \\
\hline GCG1 & $\mathbf{1 . 0 0 0}$ & -0.301 & -0.574 \\
\hline KK3 & -0.293 & $\mathbf{0 . 9 8 6}$ & 0.458 \\
\hline KK4 & -0.301 & $\mathbf{0 . 9 9 1}$ & 0.553 \\
\hline Size1 & -0.584 & 0.469 & $\mathbf{0 . 9 8 5}$ \\
\hline Size2 & -0.464 & 0.579 & $\mathbf{0 . 9 6 5}$ \\
\hline Size3 & -0.581 & 0.294 & $\mathbf{0 . 7 5 6}$ \\
\hline
\end{tabular}

Berdasarkan nilai cross loading untuk semua konstruk $>0,60$, sehingga memenuhi persyaratan discriminant validity.

\section{Pengujian Composite Reliability}

Uji reliabiltas pada model pengukuran (outer model) pada indikator reflektif dengan melihat nilai Composite Reliability. Indikator dinyatakan reliabel atau memiliki reliabilitas baik apabila nilai Composite Reliability > 0,70 . Hasil perhitungan Composite Reliabilitydalam penelitian ini, dapat dilihat pada tabel berikut :

Tabel 3. Nilai Composite Reliability

\begin{tabular}{|c|c|}
\hline & Composite Reliability \\
\hline GCG & 1.000 \\
\hline Kinerja Keuangan & 0.988 \\
\hline Size & 0.933 \\
\hline
\end{tabular}

Tabel di atas menunjukkan bahwa nilai composite reliability $>0,70$, sehingga dapat disimpulkan bahwa semua indikator konstruk adalah reliabel atau memenuhi uji reliabilitas.

\section{Persamaan Model Pengukuran (Outer Mode)}

Proses uji validitas dan uji reliabilitas telah menghasilkan model pengukuran dengan indikator yang telah valid dan reliabel. Setelah dilakukan uji validitas dan reliabilitas konstruk, maka persamaan model pengukuran (outer mode) yang memenuhi syarat convergent validity, discriminant validity dan composite reliability dalam penelitian ini sebagaimana ditunjukkan pada Tabel sebagai berikut : 
Tabel 4. Model Pengukuran (Outer Mode) yang Terbentuk

\begin{tabular}{|c|l|c|}
\hline No & \multicolumn{1}{|c|}{ Variabel } & $\begin{array}{c}\text { Model Pengukuran (Outer } \\
\text { Mode) }\end{array}$ \\
\hline \multirow{2}{*}{1} & Size $(\mathrm{X} 1)$ & $\mathrm{x} 1.1=0.985+\delta 1$ \\
\cline { 2 - 3 } & & $\mathrm{x} 1.2=0.965+\delta 2$ \\
\cline { 2 - 3 } 2 & & $\mathrm{x} 1.3=0.756+\delta 3$ \\
\hline 3 & Kinerja Keuangan $(\mathrm{Y})$ & $\mathrm{x} 2.1=1.000+\delta 1$ \\
\cline { 2 - 3 } & & $\mathrm{y} .3=0.986+\varepsilon 3$ \\
\hline
\end{tabular}

Sumber: Lampiran 2

\section{Model Struktural (Inner Model)}

Evaluasi inner model dilakukan dengan uji bootstrapping. Evaluasi model struktural (inner mode) merupakan model struktural untuk memprediksi hubungan kausalitas antar variabel laten melalui uji bootstrapping, untuk memprediksi adanya hubungan kausalitas model structural (inner model) dievaluasi dengan menggunakan $R$-square untuk konstruk dependen, Stone-Geiser Q-square test untuk predictive relevance dan uji t serta signifikansi dari koefisien parameter jalur struktural. Dalam menilai model dengan PLS dengan melihat $R$-square untuk setiap variabel laten eksogen. Hasil evaluasi inner mode/ dijelaskan sebagai berikut, untuk Tabel dibawah ini menunjukkan nilai $R$-square.

Tabel 5

Nilai $R$-square

\begin{tabular}{|c|c|}
\hline Kinerja Keuangan & 0,2660 \\
\hline
\end{tabular}

Sumber: Data Diolah

Hasil analisis pada Tabel di atas menunjukkan nilai $R$-square untuk variabel laten endogen Kinerja Keuangan adalah 0,2660 yang berarti model ini mampu menjelaskan 26,60 persen perubahan pada variabel laten endogen Kinerja Keuangan dan sisanya sebesar 73,40 persen dijelaskan oleh faktor lain.

\section{Evaluasi Predictive relevance ( $Q$ square)}

Selain dengan menggunakan metode diatas, metode lain untuk melihat model PLS juga dievaluasi dengan melihat Q-square predictive relevance untuk model konstruk. $Q$-square mengukur seberapa baik nilai observasi dihasilkan oleh model dan juga estimasi parameternya. Suatu model dianggap mempunyai nilai predictive yang relevan jika nilai Q-square lebih besar dari $0(>0)$, sedangkan nilai $Q$-square kurang dari $0(<0)$ menunjukkan bahwa model kurang memiliki predictive relevance. Nilai $Q-$ square predictive-relevance diperoleh dengan rumussebagai berikut : 


\section{Perhitungan Q-Square Predictive-Relevance}

Hasil perhitungan $Q$-square predictive-relevance pada penelitian ini adalah

$$
\begin{aligned}
\mathrm{Q}^{2} & =1-\left(1-\mathrm{R}^{2}\right) \\
& =1-(1-0,2660) \\
& =0,2660
\end{aligned}
$$

0,2660 . Hal ini berarti model dalam penelitian ini layak untuk menjelaskan variabel endogen yaitu kinerja keuangan.

\section{Pengujian Hipotesis}

Setelah analisis model dilakukan, analisis selanjutnya adalah pengujian hipotesis, analisis ini dilakukan dengan membandingkan nilai $T$ table dengan nilai $T$-statistics yang dihasilkan dari proses bootstrapping dalam PLS. Hipotesis diterima (terdukung) jika nilai $T$-statistics lebih tinggi daripada nilai $T$-table $(1,677)$ dengan signifikansi level 10 persen (two tailed) (Ghozali, 2014:85). Hasil proses bootstrapping PLS dapat dilihat pada Tabel 4.6 dan Gambar 4.3sebagai berikut :

Tabel 6. Path Coefficients (Mean, STDEV, T-Values)

\begin{tabular}{|l|c|c|c|c|c|}
\hline & $\begin{array}{c}\text { Original } \\
\text { Sample } \\
\text { (0) }\end{array}$ & $\begin{array}{c}\text { Sample } \\
\text { Mean } \\
\text { (M) }\end{array}$ & $\begin{array}{c}\text { Standar } \\
\text { d Error } \\
\text { (STERR } \\
\text { ) }\end{array}$ & $\begin{array}{c}\mathbf{T} \\
\text { Statistics } \\
\text { (| O/STE } \\
\text { RRI) }\end{array}$ & $\begin{array}{c}\mathbf{P} \\
\text { Values }\end{array}$ \\
\hline $\begin{array}{l}\text { GCG => } \\
\text { Kinerja } \\
\text { Keuangan }\end{array}$ & -0.007 & -0.001 & 0.094 & $\mathbf{0 . 0 7 6}$ & $\mathbf{0 . 9 4 0}$ \\
\hline $\begin{array}{l}\text { Size => } \\
\text { Kinerja } \\
\text { Keuangan }\end{array}$ & 0.512 & 0.520 & 0.132 & $\mathbf{3 . 8 8 2}$ & $\mathbf{0 . 0 0 0}$ \\
\hline
\end{tabular}

Sumber: Lampiran 2

Gambar 4. Hasil Proses Bootstrapping

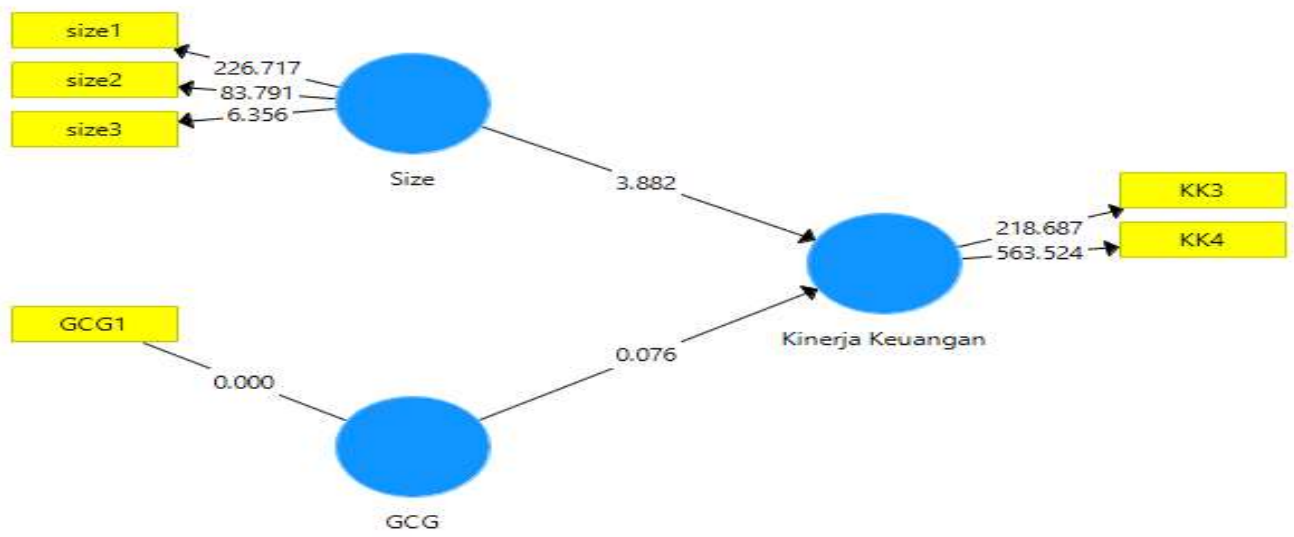


Sumber: Data diolah

Persamaan model struktural yang diperoleh berdasarkan hasil pengujian inner mode/dan pengujian hipotesis, sebagai berikut :

Kinerja Keuangan $=0,512$ Size --0.007 GCG $+\zeta$

Keterangan :

Size = Ukuran Perusahaan

GCG $=$ Good Corporate Governance

$\zeta 4$ = Inner residual variable.

\section{Pembahasan}

Berdasarkan tabel dan gambar di atas, dapat diambil kesimpulan terhadap hubungan langsung antara variabel yang sudah dihipotesiskansebagai berikut :

Pengujian PengaruhUkuran Perusahaan terhadap Kinerja Keuangan

Berdasarkan hasil analisis pada Tabel 4.6 hipotesis 1 yang menyatakan bahwa ukuran perusahaan (Size) berpengaruh signifikan terhadap kinerja keuangan, untuk nilai koefisien jalur menghasilkan nilai sebesar 0,512. Hasil uji hipotesis menunjukkan path coeficient antara partisipasi anggaran dengan senjangan anggaran memiliki nilai T-statistics $(3,882)>T$-table $(1,677)$ dengan signifikansi level 10 persen (two tailed), menunjukkan bahwa ukuran perusahaan (Size) berpengaruh positif signifikan terhadap Kinerja Keuangan. Artinya hipotesis 1 diterima.

Hal ini menunjukkan bahwa semakin besar ukuran perusahaan yang diproxikan dengan In total ekuitas, In penjualan dan In laba akan mampu meningkatkan kinerja perusahaan dalam hal ini kinerja yang diukur dari solvabilitas yaitu DAR dan DER artinya bahwa kemampuan untuk membiayai operasional perusahaan dengan modal sendiri akan menghasilkan penjualan yang pada akhirnya diperoleh laba yang optimal akan mampu menutup hutang jangka panjang perusahaan. Hal ini mendukung penelitian dari Sudarmadji dan Sularto (2007), dimana perusahaan besar yang mempunyai sumber daya yang besar pula akan melakukan pengungkapan lebih luas dan mampu membiayai penyediaan informasi untukkeperluan internal.

\section{Pengujian Pengaruh Good Corporate Governance terhadap Kinerja Keuangan.}

Berdasarkan hasil analisis pada Tabel 4.6 hipotesis 2 yang menyatakan bahwa pengaruh GCG terhadap kinerja keuangan memiliki nilai koefisien jalur sebesar -0.007 dan $T$-Stastistics $(0,076)<T$-table $(1,677)$ dengan signifikansi level 10 persen (two tailed), menunjukkan bahwa good corporate governance tidak berpengaruh dengan signifikan terhadap Kinerja Keuangan. Artinya hipotesis 2 ditolak. 
Hal ini menunjukkan bahwa mekanisme corporate governance yang diproxikan dengan kepemilikan manajerial tidak mempengaruhi kinerja perusahaan dalam hal ini kinerja yang diukur dari solvabilitas yaitu DAR dan DER dan hubungannya adalah negatif artinya bahwa kepemilikan manajerial yang tinggi tidak akan meningkatkan kinerja keuangan perusahaan terutama kemampuan dalam membayar hutang jangka panjang. Hal ini sesuai dengan teori agency bahwa kepemilikan manajerial tidak mampu menjembatani antara agen \& principle karena, jika kepemilikan manajerial semakin besar, maka akan merubah pemikiran lebih kepada kepentingan agen dalam hal ini adalah keinginan untuk mempeoleh keuntungan yang berakibat perolehan deviden sehingga pelunasan hutang jangka panjang menjadi terhambat. Hal ini mendukung penelitian dari Ross, et al (1999) dalam Tarjo (2008) menyatakan bahwa semakin besar proporsi kepemilikan manajemen pada perusahaan, maka manajemen cenderung berusaha giat untuk kepentingan pemegang saham yang tidak lain dirinya sendiri. Sehingga dapat dikatakan kepemilikan saham oleh manajemen akan membuat manajemen termotivasi dalam meningkatkan kinerja perusahaan dalam hal ini perolehan laba jangka pendek.

\section{Kesimpulan}

\section{PENUTUP}

Penelitian ini bertujuan untuk menguji pengaruh mekanisme corporate governance dan ukuran perusahaanterhadap kinerja keuangan perusahaan. Populasi adalah perusahaan yang bergerak di sektor manufaktur yang terdaftar di BEI dari tahun 2013 -2015. Teknik sampling yang digunakan adalah purposive sampling dan diperoleh 15 perusahaan dengan waktu 3 tahun sehingga jumlah sampel yang diteliti 45. Alat analisi yang digunakan adalah partial least square. Berdasarkan hasil penelitian yang dilakukan, dapat diambil kesimpulan bahwa mekanisme corporate governance tidak berpengaruh terhadap kinerja keuangan. Hal ini menunjukkan jika perusahaan banyak kepemilikan saham manajerial, maka tidak akan mampu meningkatkan kemampuan perusahaan dalam membayar hutang jangka panjang, karena akan terjadi perubahan kepentingan dari agen ke principle, sehingga hanya mementingkan keuntungan dalam jangka pendek, yang berakibat tidak memiliki kemampuan di dalam membayar hutang jangka panjang. Sedangkan ukuran perusahaan berpengaruh terhadap kinerja perusahaan yaitu jika perusahaan membiaya dengan modal sendiri, maka resiko menjadi rendah sehingga penjualan dapat ditingkatkan dan akan menghasilkan laba yang pada akhirnya akan mampu menghasilkan kinerja keuangan yang tinggi yang berakibat dapat menutup resiko dalam jangka panjang.

\section{Keterbatasan dan Saran Penelitian}


Dalam penelitian ini, terdapat beberapa keterbatasan yang apabila mampu diatasi akan dapat memperbaiki hasil penelitian. Keterbatasan tersebut adalah sebagai berikut :

1. Penelitian ini hanya menggunakan perusahaan manufaktur yang terdaftar di BEI sebagai sampel sehingga bagi peneliti selanjutnya dapat memperluas sampel tidak hanya satu sektor atau menggunakan sampel sektor yang lain.

2. Jumlah perusahaan yang menjadi sampel penelitian relative sedikit. Sedikitnya sampel ini disebabkan karena ketidaklengkapan laporan keuangan, sedangkan variabel penelitian hanya terbatas pada mekanisme corporate governance, ukuran perusahaan dan kinerja keuangan, sehingga bagi peneliti selanjutnya diharapkan dapat menambah atau menggunakan variabel lain misalnya CSR.

\section{DAFTAR PUSTAKA}

Abdurrahman, A. (2005). Ensiklopedia Ekonomi Keuangan Dan Perdagangan. Jakarta: Pradya Paramita.

Aida Ainul Mardiyah, Mei 2002. "Pengaruh Informasi Asimetri Dan Disclosure Terhadap Cost Of Capital", Jurnal Riset Akuntansi Indonesia, Vol.5 No.2, Hal 229-256. Nugraheni, Fitri Dan Dody Hapsoro. "Pengaruh Rasio Keuangan CAMEL, Tingkat Inflasi, Dan Ukuran Perusahaan Terhadap Kinerja Keuangan Perusahaan Perbankan Di Bursa Efek Jakarta". Wahana, Vol. 10, No.2, Hal: 63-80, Agustus 2007.

Ambarwati, Novi Sagita. Yuniarta, Gede Adi Dan Sinarwati, Ni Kadek. 2015. Pengaruh Modal Kerja, Likuiditas, Aktivitas Dan Ukuran Perusahaan Terhadap Profitabilitas Pada Perusahaan Manufaktur Yang Terdaftar Di Bursa Efek Indonesia. E-Journal S1 Ak Universitas Pendidikan Ganesha Jurusan Akuntansi Program S1. Volume 3 No. 1

Arini, Riska Irva, 2009, "Analisis Pengaruh Ukuran Perusahaan, Kualitas Aktiva Produktif, Likuiditas Dan Tingkat Suku Bunga Terhadap Kinerja Keuangan Bank Syariah Periode 2005-2008", Fakultas Ekonomi, Universitas Diponegoro.

Basir. Abdel-Hameed M. 2003. Determinants Of Profitability In Islamic Banks: Some Evidence From The Middle East. Islamic Economic Studies Vol. 11, No. 1, September 2003

Bjuggren, Per-Olof; Eklund, Johan E., Wiberg, Daniel. 2007. Ownership Structure, Control And Firm Performance: The Effects Of VoteDifferentiated Shares. In Applied Financial Economics 17(16):1323-1334 February

Candradewi, Intan. 2015. Pengaruh Kepemilikan Manajerial, Kepemilikan Institusional Dan Dewan Komisaris Independen Terhadap Return On 
Asset Perusahaan Otomotif Dan Komponen Di Bursa Efek Indonesia. Skripsi Fakultas Ekonomi Dan Bisnis Universitas Udayana.

Darwis, Herman. 2007 Corporate Governance Terhadap Kinerja Perusahaan. Jurnal Keuangan Dan Perbankan, Vol. 13, No 3

Dietrich, A., Wanzenried, G. (2011), Determinants Of Bank Profitability Before And During The Crisis: Evidence From Switzerland. Journal Of International Financial Markets, Institutions And Money, 21(3), 307327

Eriandani, Rizky. 2013. Pengaruh Institutional Ownership Dan Managerial Ownership Terhadap Pengungkapan CSR Pada Laporan Tahunan Perusahaan Studi Empiris Pada Perusahaan Manufaktur 2010-2011. Simposium Nasional Akuntansi XVI: Manado

Faisal, 2005. "Analisis Agency Cost, Struktur Kepemilikan Dan Mekanisme Corporate Governance Terhadap Kinerja Perusahaan", Jurnal Riset Akuntansi Indonesia Vol. 8 No.,2

Fajaryani, Atik. 2015. Analisis Faktor - Faktor Yang Mempengaruhi Integritas Laporan Keuangan (Studi Empiris Pada Perusahaan Pertambangan Yang Terdaftar Di Bursa Efek Indonesia Periode 2008-2013). Skripsi. Yogyakarta: Universitas Negeri Yogyakarta

Fama, E. And Jensen, M. (1983) Separation Of Ownership And Control. Journal Of Law And Economics, 26, 301-326. Http://Dx.Doi.Org/10.1086/467037

Ghozali, Imam. 2011. "Aplikasi Analisis Multivariate Dengan Program SPSS". Semarang: Badan Penerbit Universitas Diponegoro

. 2014. Structural Equation Modeling, Metode Alternatif Dengan Partial Least Square (PLS). Edisi 4. Semarang : Badan Penerbit Universitas Diponegoro

Gill, Amarjit Dan Obradovich, John. 2012. The Impact Of Corporate Governance And Financial Leverage On The Value Of American Firms. International Research Journal Of Finance And Economics. ISSN 14502887 Issue 91

Hapsoro, Dody. 2008. Pengaruh Mekanisme Corporate Governance Terhadap Kinerja Perusahaan: Studi Empiris Di Pasar Modal Indonesia. Jurnal Akuntansi Dan Manajemen. Vol.19, No. 3, Desember 2008

Hermalin, Benjamin E. And Weisbach, Michael S. (1991) The Effect Of Board Composition And Direct Incentives On Firm Performance. Financial Management.20(4)

Isbanah,Yuyun.2015. Pengaruh Esop, Leverage, And Ukuran Perusahaan Terhadap Kinerja Keuangan Perusahaan Di Bursa Efek Indonesia. Journal Of Research In Economics And Management (Jurnal Riset Ekonomi Dan Manajemen. Volume 15, No. 1, Januari - Juni

Jensen, M. And W. Meckling. 1976. Theory Of The Firm: Managerial Behavior, Agency, And Ownership Structure. Journal Of Financial Economics. (Vol.3): 305-360. 
Hartono, Jogiyanto. 2011. Metodologi Penelitian Bisnis: Salah Kaprah dan Pengalaman-pengalaman. BPFE. Yogyakarta.

Kosmidou, Kyriaki And Zopounidis, Constantin. 2008 Measurement Of Bank Performance In Greece. South-Eastern Europe Journal Of Economics 1 Lughianto. 2010. " Analisis Pengaruh Ukuran Kualitas Audit Terhadap Manajemen Laba Studi Pada Perusahaan Yang Melakukan IPO Di Indonesia. Fokus Ekonomi, Vol. 5 No. 2, Desember 2010, Hal: 15-31.

Macey, Jonathan $R$ And O'Hara, Maureen 2003 The Corporate Governance Of Banks. Economic Policy Review, Vol, 9, No, 1, April 2003

Nuraeni, Dini. 2010. Pengaruh Struktur Kepemilikan Terhadap Kinerja Perusahaan. Skripsi Tidak Dipublikasi. Universitas Diponegoro. Semarang

Oswald, Sharon L And Jahera Jr, John S. 1991. The Influence Of Ownership On Performance : An Empirical Study. Strategic Management Https://Doi.Org/10.1002/Smj.4250120407

Pizarro, V., S. Mahenthiran, D. Cademamartori, And C. Roberto, 2006. The Influence Of Insiders And Institutional Owners On The Value, Transparency, And Earnings Quality Of Chilean Listed Firms. Editorial Manager (Tm) For Contemporary Accounting Research Manuscript Draft, Http://Ssrn.Com/ Abstract=982697,Pp1-33.

Purno, B Listyo. Dan Khafid, Muhamad. 2013. "Pengaruh Mekanisme Good Corporate Governance Terhadap Kinerja Perbankan". Symposium Nasioanal Akuntansi XVI, 25-28 September 2013. Manado

Rosyada, F, Yulia. 2012, "Analisis Pengaruh Mekanisme Corporate Governance Terhadap Manajemen Laba Dan Kinerja Keuangan". Skripsi. Bekasi: Universitas Gunadharma.

Sam'ani. 2008. Pengaruh Good Corporate Governance Dan Leverage Terhadap Kinerja Keuangan Pada Perbankan Yang Terdaftar Di BEI Tahun 2004 - 2007. Tesis S2. Semarang: Program Pasca Sarjana UNDIP.

Sawir, Agnes, 2009, Analisis Kinerja Keuangan Teori Dan Perencanaan Keuangan Perusahaan, Penerbit, Gramedia Pustaka Umum, Jakarta.

Sekaredi, Sawitri . 2011. Pengaruh Corporate Governance Terhadap Kinerja Keuangan Perusahaan (Studi Pada Perusahaan Yang Terdaftar Di LQ45 Tahun 2005-2009). Skripsi Fakultas Ekonomi Universitas Diponegoro Semarang

Sudarmadji, A. M. Dan Lana Sularto, 2007. "Pengaruh Ukuran Perusahaan, Profitabilitas, Leverage, Dan Tipe Kepemilikan Perusahaan Terhadap Luas Voluntary Disclosure Laporan Keuangan Tahunan ", Jurnal PESAT (Psikologi, Ekonomi, Sastra, Arsitek \& Sipil), Volume 2, Universitas Gunadarma, Jakarta.

Sujono Dan Soebiantoro, U. 2007. Pengaruh Struktur Kepemilikan Saham, Leverage, Faktor Intern Dan Faktor Ekstern Terhadap Nilai 
Perusahaan. Jurnal Manajemen Dan Kewirausahan. Vol. 9. No 1. Maret: 41-48.

Suranta, Eddy Dan Pratana Puspa Merdistusi. (2005). Pengaruh Good Corporate Governance Terhadap Praktek Manajemen Laba, Konferensi Nasional Akuntansi, Peran Akuntansi Dalam Membangun Good Corporate Governance, Hal 1-8.

Suwito, Edy Dan Arleen Herawaty. 2005. "Analisis Pengaruh Karakteristik Perusahaan Terhadap Tindakan Perataan Laba Yang Dilakukan Oleh Perusahaan Yang Terdaftar Di Bursa Efek Jakarta". Simposium Nasional Akuntansi VIII Solo. 15-16 September

Tarjo. 2008. "Pengaruh Konsentrasi Kepemilikan Institusiona Dan Leverage Terhadap Manajemen Laba, Nilai Pemegang Saham Serta Cost Of Equity Capital". Simposium Nasioanal Akuntansi XI. Pontianak.

Wahidahwati, 2001. "Pengaruh Kepemilikan Manajerial Dan Kepemilikan Institusional Pada Kebijakan Hutang Perusahaan :Sebuah Perspektif Theory Agency".Simposium Nasional Akuntansi IV.

Wardhani, Ratna., (2008). "Tingkat Konservatisme Akuntansi Di Indonesia Dan Hubungannya Dengan Karakteristik Dewan Sebagai Salah Satu Mekanisme Corporate Governance", Simposiumnasional Akuntansi XI, Pontianak, 23-24 Juli

Weston,J.F Dan Brigham, 1998, Manajemen Keuangan , Edisi 9, Alih Bahasa Oleh Kirbrandoko, Jakarta : Erlangga

Wiagustini, Ni Luh Putu. 2010. Dasar-Dasar Manajemen Keuangan. Denpasar. Udayana University Press.

Wijayanti, Puput. 2012. Pengaruh Intellectual Capital Terhadap Harga Saham Melalui Kinerja Keuangan Pada Perusahaan Perbankan Yang Terdaftar Di Bursa Efek Indonesia Pada Tahun 2009-2011. Skripsi Malang Universitas Brawijaya

Wiranata, YULIUS ARDY DAN NUGRAHANTI, YETERINA WIDI. 2013 Pengaruh Struktur Kepemilikan Terhadap Profitabilitas Perusahaan Manufaktur Di Indonesia. Jurnal Akuntansi Dan Keuangan.Vol 15 No 1 